\title{
ANALISIS KESESUAIAN HARAPAN DAN PERSEPSI ATAS KUALITAS LAYANAN (SERVICE QUALITY) PADA BANK UMUM SYARIAH DI TULUNGAGUNG
}

\author{
Qomarul Huda \\ Email : qohu1973@gmail.com \\ Rokhmat Subagiyo \\ Email : mat97.eca@gmail.com
}

\begin{abstract}
Abstrak :Penelitian ini bertujuan untuk mengetahui: (1) tingkat kesenjangan antara persepsi dan harapan nasabah atas kualitas pelayanan berupa tangibles ( bukti fisik); (2) tingkat kesenjangan antara persepsi dan harapan nasabah atas kualitas pelayanan berupa reliability (kehandalan); (3) tingkat kesenjangan antara persepsi dan harapan nasabah atas kualitas pelayanan berupa responsiveness (keikutsertaan); (4) tingkat kesenjangan antara persepsi dan harapan nasabah atas kualitas pelayanan berupa assurance (jaminan \& kepastian); dan (5) tingkat kesenjangan antara persepsi dan harapan nasabah atas kualitas pelayanan berupa empathy (empati) pada bank umum syariah di kabupaten tulungagung. Sampel adalah nasabah simpanan yang pernah menggunakan layanan pada perbankan syariah di bank umum syariah di kabupaten Tulungagung dan pernah datang ke kantor layanan bank umum syariah minimal tiga (3) kali 3 bulan terakhir. Teknik analisis yang dipakai adalah analisis Tes Rangking-Bertanda Wilcoxon agar mengetahui apakah terdapat perbedaan signifikan antara pasangan-pasangan data ordinal dari dua (2) buah sampel yang berhubungan. Pengujian instrumen menggunakan uji validitas, uji reliabilitas dan uji normalitas.Hasil penelitian menunjukkan: (1) hasil uji tes rangking-bertanda wilcoxon untuk data berpasangan antara persepsi dan harapan nasabah atas kualitas pelayanan berupa tangibles (bukti fisik) terdapat kesenjangan antara persepsi dan harapan nasabah pada bank umum syariah di tulungagung; (2) hasil uji rangking-bertanda wilcoxon untuk data berpasangan antara persepsi dan harapan nasabah atas kualitas pelayanan berupa kehandalan (reliability) tidak ada kesesuaian antara persepsi dan harapan nasabah pada bank umum syariah di tulungagung,: (3) setelah data diuji rangking-bertanda wilcoxon untuk data berpasangan yang diujikan antara persepsi dan harapan pada variabel daya tanggap/keikutsertaanada kesenjangan (tidak ada kesesuaian); (4) hasil data diuji rangking-bertanda wilcoxon untuk data berpasangan yang diujikan antara persepsi dan harapan pada variabel jaminan dan kepastian atau assurance, telah sesuai dan (5) hasil uji rangking-bertanda wilcoxon untuk data berpasangan menunjukkan bahwa pegawai bank umum syariah dalam berkomunikasi telah berjalan dengan baik, dapat memahami kebutuhan khusus nasabah dan mudah dihubungi.
\end{abstract}

Kata kunci: Service Quality, Tes Rangking-Bertanda Wilcoxon, Bank Umum Syariah

Qomarul Huda, adalah Dosen Fakultas Ekonomi dan Bisnis Islam IAIN Tulungagung Rokhmat Subagiyo, adalah Dosen Fakultas Ekonomi dan Bisnis Islam IAIN Tulungagung 


\section{PENDAHULUAN}

Saat ini pertumbuhan perbankan syariah mengalami peningkatan yang signifikan.Hal ini selaras dengan permintaan nasabah untuk menjadi nasabah pada bank syariah baik menjadi nasabah penabung maupun nasabah pembiayaan.Pertumbuhan perbankan yang pesat memberikan banyak alternatif bagi nasabah dalam memilih layanan jasa yang diberikan.Dampak positif dari pertumbuhan perbankan syariah yang pesat adalah semakin ketatnya persaingan antar perbankan syariah.Sebagai penyedia jasa, perbankan syariah harus menciptakan strategi yang mampu mempertahankan nasabah yang ada dan mampu menarik nasabah baru.Sehingga pihak perbankan syariah harus memperhatikan kepuasan nasabah.

Kepuasan pelanggan dibutuhkan dalam mempertahankan keberadaan pelanggan.Keseluruhan aktivitas pada perusahaan penyedia jasa khususnya perbankan syariah harus berfokus pada nilai pelanggan atau kepuasan nasabah pada perbankan syariah.Dalam memuaskan nasabah bisa juga dengan meningkatkan pelayanan yang baik agar kepuasan nasabah meningkat. Semakin baik pelayanan yang diberikan oleh pihak perbankan syariah, maka nasabah akan tertarik dengan produk-produk atau layanan jasa yang diberikan. Oleh karena itu pihak perbankan syariah dituntut untuk benar-benar meningkatkan kepuasan nasabah.

Dengan semakin meningkatknya jumlah perbankan syariah akan mempercepat persaingan, sehingga harus memenuhi kebutuhan dan keinginan dari nasabah. Perbankan syariah harus berusaha memberikan pelayanan yang maksimal agar lebih memuaskan nasabah dibandingkan dengan perbankan syariah lain atau pesaingnya. Agar pihak bank tidak hanya terfokus hanya pada produk barang atau jasa yang dihasilkan saja, tetapi juga pada aspek proses, sumber daya manusia, serta lingkungannya. Tahap awal adalah mendefinisikan tuntutan nasabah, yaitu sesuatu hal yang harus diperhatikan dan tidak dapat dipisahkan adalah ketersediaan informasi yang menyangkut penilaian atas jasa yang telah diberikan dan harapan nasabah terhadap kualitas jasa pelayanan yang ditawarkan oleh pihak bank.

Kepuasan pelanggan dibutuhkan dalam mempertahankan keberadaan pelanggan.Keseluruhan aktivitas pada perusahaan penyedia jasa khususnya perbankan syariah harus berfokus pada nilai pelanggan atau kepuasan nasabah pada perbankan syariah.Dalam memuaskan nasabah bisa juga dengan meningkatkan pelayanan yang baik agar kepuasan nasabah meningkat. Semakin baik pelayanan yang diberikan oleh pihak perbankan syariah, maka nasabah akan tertarik dengan produk-produk atau layanan jasa yang diberikan. Oleh karena itu pihak perbankan syariah dituntut untuk benar-benar meningkatkan kepuasan nasabah.

Ada dua faktor yang diperhatikan dalam memenangkan persaingan antar bank syariah yakni faktor internal dan faktor eksternal.Faktor internal adalah faktor-faktor yang berada dalam perbankan syariah yang berkaitan dengan situasi bank itu sendiri (intern). Sedangkan faktor eksternal merupakan faktorfaktor di luar lingkungan perbankan syariah yang masih ada hubungannya dengan bank syariah tersebut. Dengan mengetahui kedua faktor tersebut diharapkan akanmenjadi faktor pertimbangan dalam menentukan jenis pelayanan yang akan ditawarkan, sehingga pelayanan akan menjadi maksimal, yakni nasabah akan mencapai kepuasan dan keuntungan optimal bisa diraih. Oleh karena itu pihak 
perbankan syariah diperlukan analisis yang mendalam berkaitan dengan tingkat kepuasan nasabah.

Penyebab seorang nasabah atau pelanggan menjadi pelanggan yang loyal akan menjadikan faktor yang sangat penting bagi perusahaan dalam meningkatkan tingkat pelayanan yang diberikan. Pelayanan tersebut dapat berupa pemberian responsive, assurance, tangibles, empathy dan reliability kepada konsumen dengan baik. Kepuasan pelanggan dapat tercipta akan memberikan beberapa kegunaan, antara lain hubungan perusahaan dan pelanggannya menjadi harmonis atau dekat. Kemudian menjadi dasar yang baik bagi pembelian ulang produk atau jasa yang ditawarkan dan akan tercipta loyalitas nasabah. Karena loyalitas nasabah, maka nasabah akan merekomendasikan ke teman-teman atau lingkungan nasabah dengan cara lisan (word of mouth).

Definisi kepuasan pelanggan menurut para pakar pemasaran, salah satunya menurut Oliver dan Swan (1989) adalah karakteristik pelanggan yang merasa surprise atas harapannya.Sedangkan menurut Bery dan Parasuraman 1985), kepuasan pelanggan sebagai perbandingan antara layanan yang diharapkan (expectation) dan kinerja (performance).Menurut Boone dan Kurtz (1995), "customer satisfaction is the ability of goods or services to meet or exceed buyer need and expectations". Jika saat pelanggan membeli dan menggunakan suatu produk, dan mampu memenuhi bahkan melampaui kebutuhan dan harapannya, maka akan terjadi kepuasan. Berdasarkan pengertian di atas terlihat bahwa kesenjangan atau gap yang dirasakan oleh pelanggan akan selalu dinilai lewat proses pembandingan yang berkelanjutan antara harapan dengan kenyataan yang diberikan oleh perusahaan.

Para penyedia produk dan layanan jasa harus memperhatikan tingkat kepuasan pelanggan yang terbagi secara umum menjadi tiga tingkat kepuasan, yaitu apabila kenyataan dibawah harapan, maka konsumen cenderung tidak puas. Selanjutnya kalau kenyataan sesuai dengan harapan, pelanggan akan puas. Sebaliknya apabila kenyataan melampaui harapan, maka pelanggan akan sangat puas. Konsep penilaian atau pengukuran kualitas pelayanan yang pernah dikembangkan SERVQUAL oleh Zeithaml, Parasuraman \& Berry (1985), yaitu tangibles, reliability, responsiveness, assurance, dan empathy. Mengukur kualitas jasa berarti melakukan evaluasi atau membandingkan antara harapan dengan kinerja yang diberikan. Pada model pengukuran tersebut, disebut dengan nama SERVQUAL. Instrumen ini dipakai dalam pengukuran harapan dan persepsi pelanggan dan kesenjangan atau gap yang ada di model kualitas jasa.

Saat ini di Tulungagung terdapat empat (4) bank syariah yang beroperasi dan memiliki kantor cabang yakni: Bank Muamalat Indonesia, Bank Syariah Mandiri, BRI Syariah dan BNI Syariah dengan bisnis yang sama yakni melakukan pengumpulan dana dari masyarakat dan menyalurkan dana kembali pada masyarakat (www.bi.go.id). Pada bank umum syariah tersebut masing-masing berlomba-lomba untuk mencari nasabah penabung maupun nasabah peminjam dengan fokus pada peningkatan kualitas pelayanan jasa.Nasabah peminjam atau pembiayaan, yakni petugas menawarkan produk-produk pinjaman atau pembiayaan pada calon nasabah dengan mendatangi rumah-rumah calon nasabah yang di anggap potensial. Oleh karena itu, akan dilakukan penelitian yang berjudul: "Kesenjangan Persepsi dan Harapan Atas Kualitas Layanan (Service Quality) pada Bank Umum Syariah di Tulungagung (Survey pada Bank Umum Syariah di Tulungagung)". 


\section{TINJAUAN PUSTAKA}

\section{Kualitas Pelayanan / Jasa \\ 1. Definisi Kualitas Pelayanan / Jasa}

Parasuraman et al (1985) mendefinisikan service quality is a function of the differences between expectation and performance along the quality dimensions. Maksudnya, kualitas pelayanan jasa adalah perbedaan antara harapan dan kenyataan yang diterima oleh pelanggan.Apakah harapan kurang sesuai dari kenyataan yang diterima pelanggan atau malah sebaliknya.Sedangkan menurut Bitner dan Hubbert (1994), kualitas pelayanan merupakan keseluruhan kesan konsumen terhadap inferioritas /superioritas organisasi beserta jasa yang ditawarkan.

Konsep kualitas pelayanan seringkali dikembangkan sebagai perbandingan antara kualitas jasa yang dipersepsikan dan diterima pelanggan dengan apa-apa yang mereka harapkan (Parasuraman et al,1985). Pada tingkat operasional banyak didominasi SERVQUAL berdasarkan pada model kesenjangan(Blomer et al, 1999). Dan telah disetujui pula bahwa kualitas pelayanan merupakan konsep multidimensi (Parasuraman et al,1985).

Konsep kualitas sendiri pada dasarnya bersifat relatif, yaitu tergantung dari perspektif yang digunakan untuk menentukan ciri-ciri dan spesifikasi kualitas yang dimaksudkan. Pada dasarnya terdapat tiga orientasi kualitas yang seharusnya konsisten satu sama lain; (1) persepsi konsumen, (2) produk (jasa), dan (3) proses.

\section{Faktor-Faktor Kualitas Pelayanan / Jasa}

Dalam salah satu studi mengenai SERVQUAL oleh Zeithaml, Parasuraman \& Berry (1990) yang melibatkan 800 pelanggan (yang terbagi dalam empat perusahaan) berusia 25 tahun keatas, disimpulkan bahwa terdapat lima dimensi SERVQUAL sebagai berikut: (1). Dimensi Pertama, dari kualitas pelayanan menurut konsep SERVQUAL adalah berwujud (tangible) yaitu kemampuan suatu perusahaan dalam menunjukkan eksistensinya kepada pihak eksternal. (2) Dimensi Kedua, yakni kehandalan (reliability) adalah dimensi yang mengukur kemampuan perusahaan untuk memberikan pelayanan sesuai dengan yang dijanjikan secara akurat dan terpercaya. (3) Dimensi Ketiga, ketanggapan (responsiveness) adalah suatu kebijakan untuk membantu dan memberikan pelayanan yang cepat (responsif) dan tepat kepada pelanggan, dengan menyampaikan informasi yang jelas. (4) Dimensi Keempat, Jaminan dan kepastian (assurance), yaitu pengetahuan kesopansantunan, dan kemampuan para pegawai perusahaanuntuk menumbuhkan rasa percaya para pelanggan kepada perusahaan. Dan (5) Dimensi Kelima, empati (emphaty) adalah memberikan perhatian yang tulus dan bersifat individual atau pribadi kepada para pelanggan dengan berupaya memahami keinginan konsumen.

\section{Pengukuran Kualitas Pelayanan}

Pengukuran kualitas pelayanan jasa banyak dikemukakan para ahli di bidang manajemen mutu antara lain dimensi-dimensi yang diperlukan untuk mengukur kualitas jasa, adalah Groonros sebagaimana dikutip oleh Edvarsson dkk, menyebutkan bahwa dimensi kualitas jasa terdiri dari enam unsur yaitu; profesionalisme dan keterampilan, sikap dan perilaku, mudah diakses dan fleksibel, 
keandalan dan sifat dapat dipercaya, menemukan kembali, reputasi dan dapat dipercaya(Sumadi, 2001).

Selanjutnya adalah enam dimensi utama dalam pengukuran kualitas jasa lembaga keuangan syariah adalah model CARTER, yaitu: (a) Compliance fully with Islamic law and principles, adalah kemampuan suatu perusahaan dalam melakukan operasional berdasarkan prinsip-prinsip syariah, seperti prinsip tauhid, prinsip keseimbangan, rinsip kehendak bebas, dan prinsip pertanggungjawaban; (b) assurance, adalah jaminan keahlian yang dimiliki oleh para karyawannya, perusahaan menjamin bahwa mereka adalah tenaga-tenaga yang ahli dibidangnya, mendapatkan pendidikan dan latihan yang tepat, berpengalaman, memiliki dedikasi yang baik, dan dapat memberi-kan hasil pelayanan dengan segera dan akurat bebas dari kesala-han, bebas dari dari kecelakaan, dan menjamin rasa aman bebas dari resiko; (c) reliability, adalah kemampuan memberikan pelayanan yang dijanjikan dengan segera, akurat dan memuaskan; (d) tangibles, adalah berupa prasarana berwujud yang digunakan oleh perusahaan yang dapat dilihat dan dirasakan oleh para pelanggannya, misalnya fasilitas fisik berupa gedung, interior, perlengkapan dan peralatan yang digunakan untuk melayani pelanggan, sarana komunikasi dan prasarana pendukung lainnya; (e) empathy, adalah kemudahan untuk melakukan hubungan secara pribadi, kekeluargaan dalam batas-batas menjunjung etika profesi. Seperti komunikasi yang baik, perhatian pribadi, mengenal nama dengan baik, memahami kebutuhan pelanggan, mau mengerti dan mendengarkan masalahmasalah yang dihadapi pelanggan dan (f) responsiveness (daya tanggap), adalah respon karyawan dalam membantu pelanggan dan memberikan pelayanan yang cepat dan tanggap, yang meliputi kesigapan karyawan dalam melayani pelanggan, kecepatan karyawan dalam menangani transaksi, dan penanganan atas keluhan pelanggan.

\section{Konsep Pelayanan Prima}

Menurut Barata (2003) Pelayanan prima adalah kepedulian kepada pelanggan dengan memberikan layanan terbaik untuk memfasilitasi kemudahan pemenuhan kebutuhan dan mewujudkan keuasannya, agar mereka selalu loyal kepada perusahaan atau organisasi.Pendapat ini diperkuat oleh Griffin (2003), Bahwa perusahaan harus mengutamakan layanan yang memuaskan kepada konsumen, sehingga terbentuk loyalitas yang sesungguhnya.

Dalam melayani nasabah, karyawan bank dituntut untuk berpenampilan semenarik mungkin, karena penampilan adalah hal pertama yang dilihat oleh nasabah. Secara umum penampilan yang prima yang ditampilkan oleh setiap pegawai bank adalah:

1. Wajar maksudnya sikap dan tindakan setiap karyawan bank tidak dibuatbuat.

2. Dalam hal berpakaian harus selalu rapi, serasi dan bersih, dan tidak menggunakan aksesoris dan make-up yang berlebihan.

3. Selalu mengucapkan salam ketika bertemu atau berpisah dengan nasabah, termasuk ucapan terima kasih.

4. Selalu bersikap optimis dan tidak pesimis serta tidak ragu-ragu dalam bertindak, sehingga mampu memberikan kepada nasabah atas layanan yang diberikan. 
5. Berprilaku yang baik lincah, gesit, mudah bergaul, dan cepat tanggap namun tidak over acting didepan nasabah atau tamu yang pada akhirnya dapat membuat nasabah jengkel.

6. Lemah lembut dan sopan santun dalam melayani tamu atau nasabah, membuat nasabah merasa dihargai oleh karyawan bank.

7. Selalu memberikan perhatian, tidak cuek dalam menghadapi tamu atau nasabah, dalam hal ini nasabah merasa memperoleh perhatian serius.

8. Selalu suka membantu sehingga nasabah merasa ringan dalam menghadapi urusannya.

Sikap dan perilaku merupakan bagian penting dalam etika perbankan. Adapun sikap dan perilaku yang harus dijalankan oleh setiap pegawai bank adalah jujur dalam bertindak dan bersikap, rajin, tepat waktu dan tidak pemalas, selalu murah senyum, lemah lembut dan ramah tamah, sopan santun tutur kata dan hormat, simpatik, bertanggung jawab dan suka menolong nasabah. Sikap melayani merupakan sikap utama dari seorang pemasar khususnya pegawai bank. Rasulullah SAW bersabda bahwa "salah satu ciri orang beriman adalah mudah bersahabat dengan orang lain, dan orang lain pun mudah bersahabat dengannya". Al-Quran memerintahkan dengan sangat ekspresif agar kaum muslim bersifat lemah lembut dan sopan santun mana kala berbicara dan melayani nasabah.

Sebagaimana Allah SWT berfirman dalam Q.S Al-Baqoroh: 83.

Artinya: Dan (ingatlah), ketika kami mengambil janji dari Bani Israil (yaitu): janganlah kamu menyembah selain Allah, dan berbuat kebaikanlah kepada ibu bapa, kaum kerabat, anak-anak yatim, dan orang-orang miskin, serta ucapkanlah kata-kata yang baik kepada manusia, Dirikanlah shalat dan tunaikanlah zakat. Kemudian kamu tidak memenuhi janji itu, kecuali sebahagian kecil daripada kamu, dan kamu selalu berpaling.(QS.AlBaqarah: 83).

\section{A. Harapan}

Tjiptono( 1997) adalah “....perkiraan atau keyakinan pelanggan tentang apa yang akan diterimanya bila ia memberi atau mengkonsumsi suatu produk (barang atau jasa)". Oleh sebab itu, harapan diyakini memiliki peranan yang besar dalam menentukan kualitas produk (barang maupun jasa) dan kepuasan konsumen.Harapan konsumen dapat merupakan keyakinan konsumen sebelum mencoba atau membeli suatu produk. Dalam mengevaluasi, konsumen akan menggunakan harapannya sebagai standar atau ukuran.

Oleh sebab itu, harapan diyakini memiliki peranan yang besar dalam menentukan kualitas produk (barang atau jasa) dan kepuasan kepuasan konsumen.Harapan konsumen dapat merupakan keyakinan konsumen sebelum mencoba atau membeli suatu produk. Dalam mengevaluasi, konsumen akan menggunakan harapannya sebagai standar atau ukuran.

\section{B. Persepsi}

Schiffman dan Kanuk (2000) mengenai definisi persepsi adalah: "Perception is defined as the process by which an individual selects, organizes, interprets stimuli into a meanignful and picture of the word". Maksudnya, persepsi adalah proses individual untuk pemilihan, pengorganisasian dan penafsiran yang merangsang sesuatu dan sesuai dengan gambaran dunia.

Jadi persepsi terbentuk melalui tiga (3) tahap, yaitu pemilihan, pengorganisasian dan penafsiran.Dalam tahap pemilihan, individu hanya memilih informasi yang berkaitan dengan kebutuhannya, mendukung keyakinannya serta 
mengingat informasi yang sesuai dan memperkuat keyakinannya.Tahap pengorganisasian persepsi adalah suatu tahapan dimana individu mengolah dan mengatur informasi yang diterima agar menjadi suatu kesatuan yang utuh.Dalam tahap ini individu cenderung untuk melihat informasi sebagai kelompok-kelompok informasi yang digolongkan berdasarkan kesamaan antar obyek.

Proses terakhir dari persepsi adalah memberikan interpretasi atas stimuli yang diterima oleh konsumen. Setiap stimuli yang menarik perhatian konsumen baik disadari atau tidak disadari, akan diinterpretasikan oleh konsumen. Dalam proses interpretasi konsumen membuka kembali berbagai informasi dalam memori yang telah tersimpan dalam waktu yang lama (long term memory) yang berhubungan dengan stimuli yang diterima. Informasi dalam long term memory akan membentuk konsumen untuk menginterprestasikan stimuli. Interprestasi itu didasarkan pengalaman-pengalaman pada masa lalu, dan pengalaman itu tersimpan dalam memori jangka panjang konsumen.

Menurut Horovitz (2000, persepsi dipengaruhi oleh tiga faktor, yakni:

1. Faktor Psikologis

Faktor psikologis akan membuat perubahan dalam persepsi konsumen. Perubahan yang dimaksudkan termasuk memori, pengetahuan, kepercayaan, nilai-nilai yang dianggap konsumen penting dan berguna.

2. Faktor Fisik

Faktor ini akan mengubah persepsi konsumen melalui apa yang konsumen lihat dan rasakan. Faktor fisik dapat memperkuat atau malah menghancurkan persepsi konsumen terhadap kualitas layanan yang diberikan oleh perusahaan.

3. Image yang terbentuk

Imageyang dimaksud disini adalah imagekonsumen terhadap perusahaan atau produk. Lebih lanjut menurut Kotler, Bowen \& Makens (1999), ketika terjadi persaingan antara 2 merek produk yang sama, konsumen bisa melihat perbedaan melalui image dari perusahaan atau merek itu sendiri. Oleh karena itu perusahaan harus mampu menciptakan image yang akan membedakannya dari pesaing. Menciptakan image yang kuat dan berbeda memerlukan kreativitas dan kerja keras. Image yang sudah tercipta harus didukung oleh segala sesuatu yang dilakukan dan dikatakan oleh perusahaan.

\section{Kepuasan Pelanggan / Nasabah}

Kepuasan pelanggan atau nasabah akhir-akhir ini menjadi fokus perhatian oleh hampir semua pihak, baik pemerintah, pelaku bisnis, konsumen dan sebagainya.Hal ini dikarenakan semakin baiknya pemahaman mereka atas konsep kepuasan nasabah sebagai strategi untuk memenangkan persaingan di dunia bisnis. Sehingga kepuasan nasabah merupakan hal yang penting bagi penyelenggara jasa, karena nasabah akan menyebarluaskan rasa puasnya kepada calon nasabah, sehingga akan menaikkan reputasi pemberi jasa atau pihak perbankan.

"dan yang mempersatukan hati mereka (orang-orang yang beriman) walaupun kamu membelanjakan semua (kekayaan) yang berada di bumi, niscaya kamu tidak dapat mempersatukan hati mereka, akan tetapi Allah telah mempersatukan hati mereka. Sesungguhnya Dia Maha gagah lagi Maha Bijaksana”. (Al-anfal: 63) 
"Maka berbicaralah kamu berdua kepadanya dengan kata-kata yang lemah lembut, Mudah-mudahan ia ingat atau takut".

Pengertian kepuasan pelanggan menurut Oliver dan Swan (1989) adalah karakteristik pelanggan yang merasa surprise atas harapannya. Sedangkan menurut Bery dan Parasuraman (1985), kepuasan pelanggan sebagai perbandingan antara layanan yang diharapkan (expectation) dan kinerja (performance).Menurut Kurtz and Boone (1995), "customer satisfaction is the ability of goods or services to meet or exceed buyer need and expectations". Jika saat pelanggan membeli dan menggunakan suatu produk, dan mampu memenuhi bahkan melampaui kebutuhan dan harapannya, maka akan terjadi kepuasan.

Menurut Engelet al(1995)menyatakan bahwa kepuasan pelanggan evaluasi purna beli di mana alternative memilih sekurang-kurangnya memberikan hasil (outcome) sama atau melampui harapan pelanggan, sedangkan ketidakpuasan timbul apabila hasil yang diperoleh tidak memenuhi harapan pelanggan. Kotler (1997) mengungkapkan bahwa kepuasan pelanggan ialah perasan senang atau kecewa seseorang yang berasal dari perbandingan antara kesannya terhadap kinerja (atau hasil) suatu produk dan harapan-harapannya.

Dari uraian definisi di atas, bisa disimpulkan bahwa kepuasan pelanggan adalah evaluasi atas post consumption atas suatu barang atau jasa. Walaupun banyak definisi mengenai kepuasan pelanggan atau nasabah yang berbeda, tetapi hal yang terpenting adalah kepuasan pelanggan tidak dapat diukur dengan ukuran yang obyektif, kepuasan pelanggan harus dilihat secara abstrak dan merupakan fenomena yang bisa diukur dengan banyak indicator.Pengukuran kepuasan pelanggan yang demikian banyak dilakukan pada berbagai industri, bahkan pada individu sekalipun.

Lebih lanjut menurut Andreassen(1994), kepuasan nasabah bisa dibentuk melalui 3 item yaitu:

1. Tingkat kepuasan terhadap pelayanan secara keseluruhan.

2. Tingkat kepuasan terhadap pelayanan apabila dibandingkan dengan jasa sejenis.

3. Keinginan mencari pelayanan serupa

\section{Faktor Utama Kepuasan Pelanggan}

Kualitas perlu dipahami dan dikelola dalam seluruh bagian organisasi kualitas jasa sendiri meliputi empat aspek (Tjiptono, 2000).

1. Pertemuan jasa (service encounter)

Pertemuan jasa merupakan segala interaksi langsung antara pelanggan dengan karyawan dan fasilitas fisik penyedia jasa.

2. Desain jasa (service design)

Desain jasa adalah proses yang dilalui pelanggan dalam rangka memperoleh suatu jasa.

3. Produktivitas jasa (service productivity)

Produktivitas jasa adalah hubungan antara kualitas dan kuantitas barang atau jasa yang diproduksi dengan kualitas sumberdaya yang dipergunakan untuk menghasilkan barang/jasa tersebut.

4. Budaya dan organisasi jasa

Kualitas jasa dapat pula dipengaruhi oleh budaya organisasi dan cara pengorganisasiannya.

Adapun strategi dalam meningkatkan kualitas jasa terdiri dari :

1. Mengidentifikasi determinan utama kualitas jasa 
2. Mengelola harapan pelanggan

3. Mengelola bukti (evidence) kualitas jasa

4. Mendidik konsumen tentang jasa

5. Mengembangkan budaya kualitas

6. Menciptakan automating quality

7. Menindaklanjuti jasa

8. Mengembangkan sistem informasi kualitas jasa

\section{E. Kesenjangan (Gaps)}

Harapan dan persepsi pada akhirnya akan menentukan tingkat kepuasan konsumen terhadap suatu pelayanan. Setelah menikmati pelayanan yang diberikan, konsumen akan membandingkan antara harapan dan persepsi mereka tentang pelayanan tersebut. Pembandingan ini disebabkan karena adanya gap atau kesenjangan yang terjadi antara persepsi konsumen dengan harapan konsumen.

Berdasarkasn gaps model of service quality di bawah, ketidaksesuaian muncul dari lima macam kesenjangan yang dapat dibagi menjadi dua kelompok, yaitu :

a. Satu kesenjangan (gap), yaitu kesenjangan kelima yang bersumber dari sisi penerima pelayanan (pelanggan).

b. Empat macam kesenjangan, yaitu kesenjangan pertama sampai dengan keempat, bersumber dari sisi penyedia jasa (manajemen).

Kesenjangan diakibatkan oleh ketidaktahuan manajemen atas pelayanan yang diharapkan oleh pelanggan.

Gaps Model of ServiceQuality

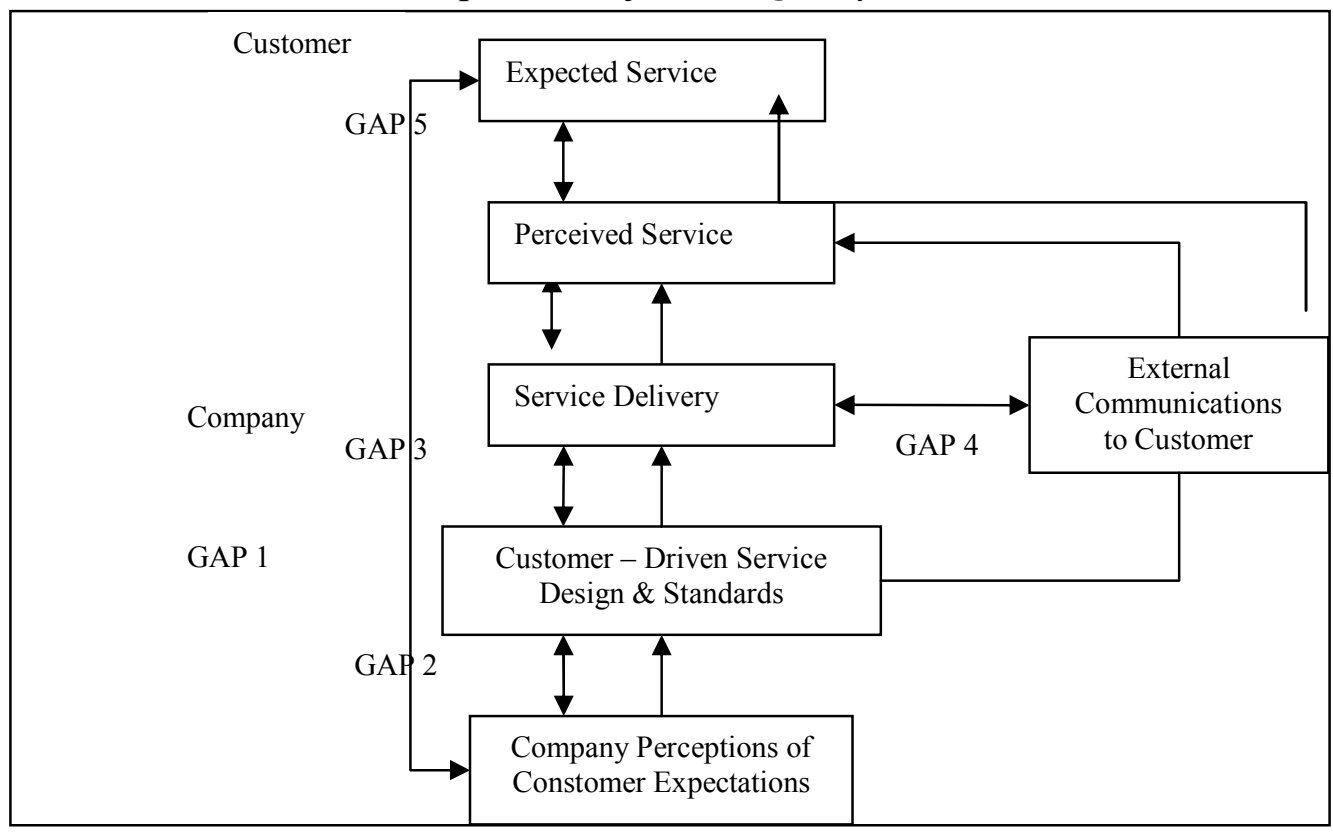

Sumber : Zeithaml dalam Freddy Rangkuti (2002), Measurung Customer Satisfaction, PT. Gramedia Pustaka utama, Jakarta 
Penelitian ini akan mengkaji terhadap kesenjangan persepsi dan harapan yang dikembangkan oleh William L. Wilkie, lebih lengkapnya akan melakukan kajian kesenjangan antara persepsi dan harapan nasabah atas kualitas pelayanan jasa yang dikermbangkan oleh Zeithmal, Bery dan Parasuraman (1996) .

\section{METODE}

Penelitian ini memiliki hipotesa penelitian sebagai berikut: Pertama, tidak terdapat kesenjangan antara harapan nasabah danpersepsi nasabah atas kualitas pelayanan pada Bank Umum Syariah. Kedua, terdapat kesenjangan antara harapan nasabah danpersepsi nasabah atas kualitas pelayanan pada Bank Umum Syariah.

Penelitian ini dilakukan dengan pendekatan kuantitatif dengan menggunakan penelitian survey. Teknik pengambilan sampel yang digunakan adalah purposive sampling adalah teknik penentuan sampel dengan mengambil sampel yang didasarkan pada pertimbangan tertentu Kriteria yang digunakan untuk mengambil sampel adalah nasabah simpanan yang pernah menggunakan layanan pada perbankan syariah di bank umum syariah di kabupaten Tulungagung dan pernah datang ke kantor layanan bank umum syariah minimal tiga (3) kali serta paling 3 bulan terakhir.

Teknik pengumpulan data dilakukan dengan menggunakan angket.Analisis data yang digunakan adalah uji validitas, uji reliabilitas, uji normalitas dan Tes Rangking-Bertanda Wilcoxon agar mengetahui apakah terdapat perbedaan signifikan antara pasangan-pasangan data ordinal dari dua (2) buah sampel yang berhubungan (Sugiyono, 207).

\section{PEMBAHASAN}

Hasil penelitian menunjukkan bahwa: Pertama, setelah tes rangkingbertanda Wilcoxon untuk data berpasangan yang diujikan antara persepsi dan harapan pada variabel bukti fisik, maka dihasilkan nilai signifikansi value sebesar 0,040 , di bawah tingkat signifikansi yang telah ditetapkan yaitu $\alpha=0,05$ maka $\mathrm{H} 0$ ditolak atau Ha diterima. Hal ini menunjukkan bahwa variabel bukti fisik atau tangibles ada kesenjangan antara persepsi dan harapan nasabah pada Bank Umum Syariah di Tulungagung.Kedua, data diuji rangking-bertanda Wilcoxon untuk data berpasangan yang diujikan antara persepsi dan harapan pada variabel kehandalan, maka dihasilkan nilai signifikansi value sebesar 0,042, lebih kecil dari tingkat signifikansi alpha $(\alpha)=0,05$ maka $\mathrm{H} 0$ ditolak atau Ha diterima. Ketiga, Setelah data diuji rangking-bertanda Wilcoxon untuk data berpasangan yang diujikan antara persepsi dan harapan pada variabel daya tanggap/keikutsertaan, dihasilkan nilai signifikansi value sebesar 0,000 , lebih kecil dari tingkat signifikansi alpha $(\alpha)=0,05$ maka H0 ditolak atau Ha diterima. Hal ini menunjukkan bahwa variabel daya tanggap/keikutsertaan atau responsiveness ada kesenjangan (tidak ada kesesuaian) antara persepsi dan harapan nasabah pada Bank Umum Syariah di Tulungagung.Keempat, data diuji rangking-bertanda Wilcoxon untuk data berpasangan yang diujikan antara persepsi dan harapan pada variabel jaminan dan kepastian atau assurance, dihasilkan nilai signifikansi value sebesar 0,065, lebih tinggi dari tingkat signifikansi alpha $(\alpha)=0,05$ maka $\mathrm{H} 0$ diterima atau Ha ditolak. Hal ini menunjukkan bahwa variabel jaminan dan kepastian atau assurance telah sesuai antara persepsi dan harapan nasabah pada Bank Umum Syariah di Tulungagung.Kelima, Hasil uji Rangking-Bertanda Wilcoxon untuk data berpasangan (lampiran 5) dihasilkan nilai $\mathrm{Z}=5,023>1,96$ dengan nilai $\mathrm{P}=0,078$, 
lebih besar daripada signifikansi $\alpha$ sebesar yang ditetapkan yaitu $\mathrm{P}=0,05$, maka $\mathrm{H} 0$ diterima atau Ha ditolak. Hal ini menunjukkan bahwa pegawai Bank Umum Syariah dalam berkomunikasi telah berjalan dengan baik, dapat memahami kebutuhan khusus nasabah dan mudah dihubungi.

Setelah pengujian data harapan dan persepsi nasabah diuji dengan Tes Rangking-Bertanda Wilcoxon untuk data berpasangan diperoleh nilai $Z=-6,920$ dengan nilai $\mathrm{P}=0,000$. Dengan demikian nilai $\mathrm{Z}$ berada di dalam penolakan $\mathrm{H} 0$ atau penerimaan Ha.Hal ini menunjukkan bahwa persepsi nasabah pada Bank Umum Syariah di Tulungagung secara keseluruhan mengenai variabel-variabel yang melekat pada kualitas pelayanan (service quality) masih terdapat kesenjangan (nasabah belum puas).

Hal ini sesuai dengan hasil penelitian yang dilakukan oleh Agus Sukoco dan Sengguruh Nilowardono, yang mengatakan bahwa PLN belum bisa memberikan layanan prima dalam hal service quality seperti yang di persepsikan oleh pelanggan terhadap jasa yang akan diterimanya dari penyedia jasa hal ini terbukti dari adanya ketidak sesuaian antara harapan dan persepsi pelanggan atas service quality yang dirasakannya (Sukoco dan Nilowardono, 2009).

Pada tabel ditunjukkan untuk menampilkan hasil uji hipotesis secara keseluruhan. Tabel ini akan mempermudah dalam memahami hasil uji analisis yang dibahas pada bagian-bagian sebelumnya. Tabel ini merangkum seluruh hasil uji hipotesis baik dari tiap-tiap variabel ataupun pada masing-masing item pernyataan dari kuesioner. Berikut ini tabel rangkuman pada hasil uji hipotesis:

Tabel 1

Rangkuman Hasil Uji Hipotesis Keseluruhan

\begin{tabular}{|c|l|l|l|}
\hline No & \multicolumn{1}{|c|}{ Variabel } & \multicolumn{1}{|c|}{$\begin{array}{c}\text { Sig (P } \\
\text { Value) }\end{array}$} & \multicolumn{1}{|c|}{$\begin{array}{c}\text { Sesuai/Tidak } \\
\text { Sesuai }\end{array}$} \\
\hline A & Bukti Fisik (Tangibles) (X1.1) & 0,040 & Tidak Sesuai \\
\hline 1 & $\begin{array}{l}\text { Kantor Bank Umum Syariah dijangkau dan } \\
\text { tidak jauh dari pusat kegiatan ekonomi }\end{array}$ & 0,000 & Tidak Sesuai \\
\hline 2 & $\begin{array}{l}\text { Tempat parkir kantor Bank Umum Syariah } \\
\text { memadai dan nyaman }\end{array}$ & 0,62 & Sesuai \\
\hline 3 & $\begin{array}{l}\text { Ruang publik atau tempat pelayanan yang } \\
\text { dimiliki kantor Bank Umum Syariah } \\
\text { nyaman }\end{array}$ & 0,000 & Tidak Sesuai \\
\hline 4 & $\begin{array}{l}\text { Peralatan kantor Bank Umum Syariah yang } \\
\text { dimiliki modern dan memadai }\end{array}$ & 0,000 & Tidak Sesuai \\
\hline 5 & Perilaku karyawan santun dan islami & 0,000 & Tidak Sesuai \\
\hline 6 & $\begin{array}{l}\text { Brosur dan formulir Bank Umum Syariah } \\
\text { lengkap dengan tampilan visual yang } \\
\text { menarik }\end{array}$ & 0,000 & Tidak Sesuai \\
\hline B & Kehandalan (Reliability) (X1.2) & 0,042 & Tidak Sesuai \\
\hline 1 & Informasi saldo sangat akurat & 0,053 & Sesuai \\
\hline 2 & Catatan transaksi/rekening sangat akurat & 0,000 & Tidak Sesuai \\
\hline
\end{tabular}


24 MODERNISASI, Volume 11, Nomor 1, Februari 2015

\begin{tabular}{|c|c|c|c|}
\hline No & Variabel & $\begin{array}{l}\text { Sig }(P \\
\text { V alue) }\end{array}$ & $\begin{array}{c}\text { Sesuai/Tidak } \\
\text { Sesuai }\end{array}$ \\
\hline 3 & $\begin{array}{l}\text { Informasi yang diberikan oleh karyawan } \\
\text { akurat dan memuaskan }\end{array}$ & 0,000 & Tidak Sesuai \\
\hline $\mathrm{C}$ & $\begin{array}{l}\text { Daya Tanggap/Keikutsertaan } \\
(\text { Responsiveness })(\mathrm{X} 1.3)\end{array}$ & 0,00 & Tidak Sesuai \\
\hline 1 & $\begin{array}{l}\text { Kepekaan karyawan terhadap kebutuhan } \\
\text { nasabah satu dengan yang lain berbeda }\end{array}$ & 0,085 & Sesuai \\
\hline 2 & $\begin{array}{l}\text { Kemampuan untuk memberikan pelayanan } \\
\text { sesuai dengan kebutuhan masing-masing } \\
\text { nasabah }\end{array}$ & 0,01 & Tidak Sesuai \\
\hline 3 & $\begin{array}{l}\text { Kecepatan dan ketepatan dapat } \\
\text { menyelesaikan setiap transaksi }\end{array}$ & 0,000 & Tidak Sesuai \\
\hline $\mathrm{D}$ & Jaminan dan Kepastian (Assurance)(X1.4) & 0,65 & Sesuai \\
\hline 1 & $\begin{array}{l}\text { Kemampuan para karyawan Bank Umum } \\
\text { Syariah mampu menanamkan kepercayaan } \\
\text { kepada nasabah }\end{array}$ & 0,00 & Tidak Sesuai \\
\hline 2 & $\begin{array}{l}\text { Rasa aman bagi nasabah dalam melakukan } \\
\text { transaksi }\end{array}$ & 0,068 & Sesuai \\
\hline 3 & $\begin{array}{l}\text { Pengetahuan karyawan dapat memberikan } \\
\text { layanan kepada nasabah }\end{array}$ & 0,000 & Tidak Sesuai \\
\hline 4 & Kerahasiaan nasabah terjamin & 0,070 & Sesuai \\
\hline $\mathrm{E}$ & Empati (Emphaty)(X1.5) & 0,078 & Sesuai \\
\hline 1 & $\begin{array}{l}\text { Karyawan Bank Umum Syariah ramah pada } \\
\text { semua nasabah sehingga menimbulkan } \\
\text { perasaan nyaman dalam bank }\end{array}$ & 0,081 & Sesuai \\
\hline 2 & $\begin{array}{l}\text { Karyawan Bank Umum Syariahtersenyum } \\
\text { dan menghormati semua nasabah saat } \\
\text { melakukan transaksi }\end{array}$ & 0,076 & Sesuai \\
\hline 3 & $\begin{array}{l}\text { Karyawan Bank Umum Syariah selalu } \\
\text { mendengarkan, menghargai dan memberi } \\
\text { solusi pada saat keluhan nasabah }\end{array}$ & 0,000 & Tidak Sesuai \\
\hline & Total & 0,00 & Tidak Sesuai \\
\hline
\end{tabular}

Sumber: sumber primer, diolah

Tabel di atas bisa diambil kesimpulan bahwa sebagian besar dari kelima variabel dan sub-sub variabel yang ada didalamnya tidak sesuai atau terdapat kesenjangan antara harapan dan persepsi nasabah serta sebagian lainnya sesuai atau sudah memenuhi harapan nasabah simpanan pada Bank Umum Syariah di Tulungagung.

\section{KESIMPULAN}

Penelitian ini menghasilkan kesimpulan bahwa: Pertama, Berdasarkan hasil uji Tes Rangking-Bertanda Wilcoxon untuk data berpasangan antara persepsi 
dan harapan nasabah Atas Kualitas Pelayanan berupa Tangibles (Bukti Fisik) terdapat kesenjangan atau tidak ada kesesuaian antara persepsi dan harapan nasabah pada Bank Umum Syariah di Tulungagung, karena nilai signifikansi value sebesar 0,040 , di bawah tingkat signifikansi yang telah ditetapkan yaitu $\alpha=0,05$ maka H0 ditolak atau Ha diterima. Kedua, Hasil uji Rangking-Bertanda Wilcoxon untuk data berpasangan antara persepsi dan harapan nasabah Atas Kualitas Pelayanan berupa kehandalan (Reliability) terdapat kesenjangan atau tidak ada kesesuaian antara persepsi dan harapan nasabah pada Bank Umum Syariah di Tulungagung, karena nilai signifikansi value sebesar 0,042 , di bawah tingkat signifikansi yang telah ditetapkan yaitu $\alpha=0,05$ maka $\mathrm{H} 0$ ditolak atau Ha diterima. Ketiga, Setelah data diuji rangking-bertanda Wilcoxon untuk data berpasangan yang diujikan antara persepsi dan harapan pada variabel daya tanggap/keikutsertaan, dihasilkan nilai signifikansi value sebesar 0,000, lebih kecil dari tingkat signifikansi alpha $(\alpha)=0,05$ maka H0 ditolak atau Ha diterima. Hal ini menunjukkan bahwa variabel daya tanggap/keikutsertaan atau responsiveness ada kesenjangan (tidak ada kesesuaian) antara persepsi dan harapan nasabah pada Bank Umum Syariah di Tulungagung.Keempat, Hasil data diuji rangking-bertanda Wilcoxon untuk data berpasangan yang diujikan antara persepsi dan harapan pada variabel jaminan dan kepastian atau assurance, dihasilkan nilai signifikansi value sebesar 0,065, lebih tinggi dari tingkat signifikansi alpha $(\alpha)=0,05$ maka H0 diterima atau Ha ditolak. Hal ini menunjukkan bahwa variabel jaminan dan kepastian atau assurance telah sesuai antara persepsi dan harapan nasabah pada Bank Umum Syariah di Tulungagung.Kelima, Hasil uji Rangking-Bertanda Wilcoxon untuk data berpasangan (lampiran 5) dihasilkan nilai $\mathrm{Z}=5,023>1,96$ dengan nilai $\mathrm{P}=0,078$, lebih besar daripada signifikansi $\alpha$ sebesar yang ditetapkan yaitu $\mathrm{P}=0,05$, maka $\mathrm{H} 0$ diterima atau Ha ditolak. Hal ini menunjukkan bahwa pegawai Bank Umum Syariah dalam berkomunikasi telah berjalan dengan baik, dapat memahami kebutuhan khusus nasabah dan mudah dihubungi.Keenam, Dan secara keseluruhan (total) dari kelima variabel yang dipakai tidak terjadi kesesuaian antara persepsi dan harapan, karena diperoleh nilai $Z=-6,920$ dengan nilai $\mathrm{P}=0,000$. Dengan demikian nilai $\mathrm{Z}$ berada di dalam penolakan $\mathrm{H} 0$ atau penerimaan Ha.Hal ini menunjukkan bahwa persepsi nasabah pada Bank Umum Syariah di Tulungagung secara keseluruhan mengenai variabel-variabel yang melekat pada kualitas pelayanan (service quality) masih terdapat kesenjangan (nasabah belum puas).

\section{DAFTAR PUSTAKA}

Adya Barata, Atep, 2003. Dasar-Dasar Pelayanan Prima Jakarta: Elek Media Komputindo.

Andreassen, Tor Wallin, 1994."Satisfaction Loyalty and Reputation as Indicators of Customer Orientation in the Public Sector", International Journal of Public Sector Management, Vol.7 No.2.

Apriani, Azkah, 2012. “Analisis Harapan dan Persepsi Nasabah Atas Service quality di Bank Syariah Mandiri (Survey pada Bank Syariah Mandiri 
Kantor Cabang Pembantu Malabar Tangerang)," Skripsi-IAIN Syeikh Nurjati-Cirebon.

Antonio, Syafi'i., 2001."Bank Syari'ah Dari Teori Kepraktik”, Jakarta: Gema Insani Press

Bitner, Mary Jo dan A.R. Hubbert, 1994."Encounter Satisfaction Versus Overall Satisfaction Versus Quality: The customer's Voice In Service Quality, New Direction In Theory and Practice, Sage Publication.

Blomer, Josoe. Ko De Ruyter dan Martin Netzels,1999. "Linking Perceved Service Quality and Service Quality: A Multi-dimensional Perspective", European Journal of Marketing, Vol. 33, No.11/12.

Departemen Agama RI, 2007. al-Qur'an Terjemah Per-Kata, Bandung: Syaamil International

Engel, James F., and Roger D., Blackwell. 1995.Cinsumer Bahavior. New York : College Publishing All Right Reserved, 1993. Edisi Bahasa Indonesia. Jakarta: Bina Rupa Aksara.

Griffin, Jill. 2003. Pemasaran jasa dan kualitas pelayanan: Bagaimana mengelola kualitas pelayanan agar memuaskan pelanggan, edisi pertama. Malang: PT. Bayumedia Publishing.

Horovitz ,J., 2000.Seven Secrets Of Service Strategy, Great Britain: Prentice Hall.

Karim, Adiwarman, 2003. Ekonomi Islam: Suatu Kajian Kontemporer., Jakarta: Gema Insani Press.

Kotler, P., J. Bowen \& Makens, 1999.Marketing For Hospitality And Tourism. $2^{\text {nd }}$. New Jersey: Prentice Hall.

Louis E., Boone and David L. Kurtz. 1995.Contemporary Marketing Plus. Eight Edition. (International Edition, The Dryden Press.

Muhammad, 2011.Managemen Bank Syari'ah, edisi revisi cet. ke-2, Yogyakarta: UPP STIM YKPN.

Oliver, Richard L dan Jhon E Swan, 1989.“Consumer Perceptions of Interpersonal Equity and Satisfaction in Transaction: a Field Survey Approach", Journal Marketing.

Pusat Bahasa Departemen Pendidikan Nasional, 2005.Kamus Besar Bahasa Indonesia, edisi ke-3. Jakarta: Balai Pustaka.

Parasuraman, A., Zeithaml, V.A. and Berry, L.L. 1985. "A conceptual model of service quality and its implications for future research", Journal of Marketing, Vol. 49 No. 3.

Rakhmat, J., 2001. Psikologi Komunikasi, Bandung : PT. Remaja Rosdakarya. 
Schiffman , Leon G. dan Leslie Lazar Kanuk, 2000. Consumer Behavior. New Jersey: Prentice Hall.

Sekaran, Uma, 2000. Research Methods For Business A Skill Building Approach, New York: John Wiley.

Sugiyono, 2007.Metode Penelitian Administrasi. Bandung: Alfabeta.

Sujianto, Agus Eko. 2009. Aplikasi Statistik dengan SPSS 16.0. Jakarta: Prestasi Pustaka.

Sukoco, Agus dan Sengguruh Nilowardono, 2009.Analisa Harapan dan Persepsi Pelanggan Atas Service Quality diPT. PLN (Persero) APJ Surabaya Utara, Jurnal Ekonomi, Vol. 9 No. 2 Agustus.

Sumadi, 2001."Konsep dan Teknik Mengukur Kualitas Produk Jasa”, Jurnal: Sinergi Kajian Bisnis dan Manajemen, Vol. 4, No. 1, h. 60, kolom 4

Thori G. Dan Utus. H, 2006.Marekting Muhammad.Jakarta: Gema Insani Press.

Tjiptono, Fandy, 1997. Strategi Pemasaran. Edisi Kedua. Yogyakarta: Penerbit Andi.

Undang-Undang RI No. 21 tahun 2008 tentang Perbankan Syariah, Bab I Ketentuan Umum, Pasal 1.

Umar, Husein, 2005. Riset Sumber Daya Manusia Dalam Organisasi. Cetakan Ketiga. Jakarta : PT. Gramedia Pustaka Utama.

Wilkie, Willian L. 1994. Consumer Behavior. Third ed. New York : John Wiley \& Sons.

Winardi, 1998.Kamus Ekonomi (Inggris-Indonesia), Bandung: Penerbit Mandar Maju. 